\title{
Application of composite reinforcement for modernization of buildings and structures
}

\author{
Alina Cherkas ${ }^{1 *}$, Vladimir Rimshin ${ }^{2}$ \\ ${ }^{1}$ Moscow state university of civil engineering, Yaroslavskoye shosse, 26, Moscow, Russia, 129337 \\ ${ }^{2}$ Moscow state university of civil engineering, Yaroslavskoye shosse, 26, Moscow, Russia, 129337
}

\begin{abstract}
Properties of new reinforcing element - composite reinforcement, are considered. Feasibility study of using this material for modernization of buildings, namely for vertical extension with additional storey, is carried out. Comparative analysis of performance is conducted for metal and composite reinforcement, as well as calculations are performed which results will be used for determination of advantages and disadvantages of this innovative reinforcing method. An important factor for development of projects of building vertical extension after quite a long operation period is a proper selection of construction materials and strength analysis considering the structures to be erected. Calculation of a floor slab erected with using composite fiberglass reinforcement is represented. Results obtained in the calculation and the analysis of the data prove high efficiency of this reinforcing method through the decrease of loads on lower storeys of the building, economic feasibility and other factors.
\end{abstract}

\section{Introduction}

During its long history construction industry has experienced a great number of changes. Today, there is a variety of scientific developments and innovations introduced which can manifold improve construction quality and reliability of the construction process. This paper describes a new reinforcing element - high-strength non-metallic reinforcement made of composite materials. Fiberglass reinforcement is represented by extra strong rods with diameter from 4 to $20 \mathrm{~mm}$ with spiral-shaped ribbed surface available in any construction length. Composite fiberglass reinforcement is designed for use in concrete structures with pretensioned and non-tensioned reinforcement instead of conventional steel rebars. Non-metallic reinforcement is manufactured in the form of rods with spirally ribbed surface produced from glass or basalt fibers soaked with chemically resistant polymer. Composite materials are a group of rebars which differ by type of raw material and consist of two or more components. The first element - fibers produced from various types of raw materials, the second — thermosetting or thermoplastic polymer (resin) [1-4].

\footnotetext{
*Corresponding author: alina.tcherkas@yandex.ru
} 


\section{Materials and Methods}

While exploring the topic of structure strengthening, it is worth mentioning that during a significant period of time steel rebars have been used for reinforcing concrete structures. Main disadvantages of this type of reinforcement are corrosion and electrical conductivity. These facts encouraged researchers to improve quality of reinforcing elements, and among other consequences was creation of non-metallic composite reinforcement. Composite reinforcement was developed as a consequence of the fact that steel rebars not always comply with the service standards on structures intended for operation in corrosive environment due to corrosion and lack of antimagnetic and dielectric properties required for many articles and structures, and also because they cannot provide for light weight of the reinforced structures. However, in case of building vertical extension even with only one storey, strengthening of floor structure raises many questions concerning reliability and light weight of the new structure, as well as stability of the existing one. Provision of solutions for these questions will substantially help to strengthen the structure and extend its service life without need for regular repairs [5-7].

\section{The main part}

The simplest and most efficient technology for vertical extension is erection of usable roof levels which provide up to $20-25 \%$ of additional living space with cost not exceeding 45 $50 \%$ of new construction. In this case, it's essential to obtain data which confirm efficiency of the selected method of floor structure strengthening. Above all, attention should be paid to performance comparison of floor reinforcing materials.

Let's consider the advantages of composite reinforcement which include absence of electrical conductivity, high resistance to corrosive environment, high tensile strength, light weight, and the same for the finished structure.

However, it also has disadvantages which are worth mentioning. Among them: Composite reinforcement is not suitable for bending on site, as the shape is determined by drawings and configured by reinforcement rod during manufacturing. Heating up to $550^{\circ} \mathrm{C}$ leads to softening of binder contained in the composite material, which results in total loss of thermal insulating properties and require further measures to provide thermal insulation. Due to this fact, use of electric welding is excluded. Besides, elastic modulus of composite rebars is 3-5 times lower than that of steel structures. It means that for one and the same diameter fiberglass reinforcement will show much heavier deflection than their steel analogues. These characteristics allow successful using this material for construction of basements and foundations. However, use of this type of reinforcement in floor structures requires further calculations (i.e. quantity, surface area, material, diameter, etc.) $[8,9]$.

Further on, we will represent the comparative characteristics of the next material steel rebars. Their main advantages include very high strength as compared to non-metallic analogues, high resistance to various impacts, including chemical attack, sufficient flexibility for performing construction operations, as well as possibility to use welding for connection.

However, in spite of all the advantages, there are also some disadvantages: high density results in considerable weight of such system and the fact that steel rebars are highly susceptible to corrosion, which jeopardizes service life of the materials.

The main factor for vertical extension with one storey is compliance with design loads associated with such modernization of the building. In this case, use of composite reinforcement for strengthening the floor being constructed is the most cost effective technical and economic solution. Further operation of the building shall be taken into 
account, as well as the fact that use of non-metallic reinforcement will extend service life of structures by 2-3 times as compared to metal reinforcement, especially when operated in corrosive environment including chlorine salts, alkalies and acids. It should be emphasized that metal rebars incorporated into floor structures and other reinforced concrete structures are the most critical, but also most weak and vulnerable part. Influenced by moisture and alkali contained in concrete metal rebars suffer from corrosion, that leads to limited service life, need for repair and eventually to destruction of reinforced concrete articles and structures. In order to provide for proper service life of reinforced concrete structures fiberglass reinforcement is utilized, that leads to long-term preservation of the buildings and structures being erected.

Table 1 below shows performance comparison of metallic and fiberglass reinforcement.

Table 1. Comparative characteristics of metallic and fiberglass reinforcement

\begin{tabular}{|c|c|c|}
\hline Characteristics & $\begin{array}{l}\text { Metallic reinforcement } \\
\text { A400C Class according to } \\
\text { GOST 5781-82 }\end{array}$ & $\begin{array}{c}\text { Non-metallic composite } \\
\text { fiberglass reinforcement (ACП), } \\
\text { according to Tech. Spec. 2296- } \\
001-12655746-2012\end{array}$ \\
\hline Material & Steel $35 \Gamma \mathrm{C}, 25 \Gamma 2 \mathrm{C}$ and other & $\begin{array}{l}\text { ACח - glass fibers with diameter } \\
13-16 \text { microns with polymer } \\
\text { binder. }\end{array}$ \\
\hline Tensile strength, MPa & 360 & 1,200 \\
\hline Elastic modulus, $\mathrm{MPa}$ & 14 & 2.2 \\
\hline $\begin{array}{l}\text { Percentage elongation, } \\
\%\end{array}$ & $\begin{array}{l}\text { Curved line with yield plateau } \\
\text { under load }\end{array}$ & $\begin{array}{l}\text { Straight line of linear elastic } \\
\text { dependency under load below } \\
\text { failure }\end{array}$ \\
\hline $\begin{array}{l}\text { Behavior under load } \\
\text { (stress-strain curve) }\end{array}$ & $13-15$ & 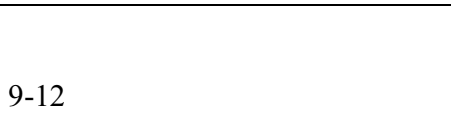 \\
\hline Density, $\mathrm{t} / \mathrm{m} 3$ & 7 & 1.9 \\
\hline $\begin{array}{l}\text { Resistance to corrosive } \\
\text { environment }\end{array}$ & Corrosion with rust formation & $\begin{array}{l}\text { Corrosion-proof material of the } \\
\text { first chemical resistance group } \\
\text { including resistance to alkali } \\
\text { environment of the concrete. }\end{array}$ \\
\hline Thermal conductivity & Yes & No \\
\hline Electrical conductivity & Yes & No, dielectric \\
\hline Profiles produced & $6-80$ & $4-20$ \\
\hline Length & Rods with length 6-12 m & $\begin{array}{l}\text { Various length on customer's } \\
\text { request }\end{array}$ \\
\hline $\begin{array}{l}\text { Environmental } \\
\text { friendliness }\end{array}$ & Environmental friendly & $\begin{array}{l}\text { Safety and health certificate } \\
\text { available, no hazardous or } \\
\text { poisoning emissions }\end{array}$ \\
\hline Durability & $\begin{array}{l}\text { According to construction } \\
\text { standards }\end{array}$ & $\begin{array}{l}\text { Expected lifetime not less than } 80 \\
\text { years. }\end{array}$ \\
\hline $\begin{array}{l}\text { Replacement for rebars } \\
\text { in terms of physical } \\
\text { and } \\
\text { properties }\end{array}$ & $\begin{array}{l}6 \mathrm{~A} 4400 \mathrm{C} \\
10 \mathrm{~A} 400 \mathrm{C} \\
12 \mathrm{~A} 400 \mathrm{C} \\
14 \mathrm{~A} 400 \mathrm{C} \\
16 \mathrm{~A} 400 \mathrm{C} \\
18 \mathrm{~A} 400 \mathrm{C}\end{array}$ & $\begin{array}{l}\text { АСП-4 } \\
\text { АСП-6 } \\
\text { АСП-8 } \\
\text { АСП-10 } \\
\text { АСП-12 } \\
\text { АСП-14 }\end{array}$ \\
\hline 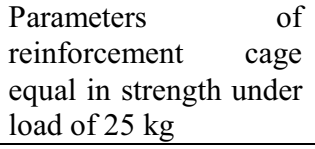 & $\begin{array}{l}\text { When using rebars } 8 \text { A } 400 \mathrm{C} \text {, mesh } \\
\text { size } 14 \times 14 \mathrm{~cm} \text {, weight } 5.5 \mathrm{~kg} / \mathrm{m} 2\end{array}$ & $\begin{array}{l}\text { When using rebars } 8 \text { ACח, mesh } \\
\text { size } 23 \times 23 \mathrm{~cm} \text {, weight } 0.61 \mathrm{~kg} / \mathrm{m} 2 \\
\text { Less weight by } 9 \text { times }\end{array}$ \\
\hline
\end{tabular}




\begin{tabular}{|l|l|l|}
\hline Cost saving & $\begin{array}{l}\text { Today, metal cost tends to rise by } \\
67 \% \text { on average during last } 6 \\
\text { months }\end{array}$ & $\begin{array}{l}\text { Money saving from replacement of } \\
\text { metallic rebars with composite } \\
\text { reinforcement of equal strength is } \\
10-30 \% . \text { Price growth dynamics is } \\
2-4 \% \text { per year }\end{array}$ \\
\hline
\end{tabular}

Use of fiberglass reinforcement for strengthening concrete structures is possible due to specific properties of this material: fiberglass has high tensile strength; temperature deformation coefficient of glass insignificantly differs from that of concrete. One of the methods of strengthening concrete with fiberglass provides for using it as part of highstrength fiberglass reinforcement [14]. Calculation technique for brief analysis of floor slab shown below is based on strength characteristics of metal and fiberglass. Below we introduce grounds for calculation method of replacement of metal reinforcement with fiberglass reinforcement.

Input data:

Tensile strength: for metal $\sigma_{\text {мет }}=390 \mathrm{MPa}, \sigma_{\text {асп }}=1000 \mathrm{MPa}$.

Ratio $\sigma_{\text {мет }} / \sigma_{\text {асп }}-$ determines conversion coefficient:

$$
K=\sigma_{\text {асп }} / \sigma_{\text {мет }}=1000 / 390=2,56
$$

as $\sigma_{\text {мет }}$ and $\sigma_{\text {асп }}$ - are loads per unit square, so conversion coefficient can be applied to cross section ratio:

where

$$
\mathrm{A}_{\mathrm{acп}}=\frac{\mathrm{A}_{\mathrm{Mет}}}{K}
$$

$\mathrm{A}_{\mathrm{acn}}$ - cross-section area of fiberglass reinforcement,

$A_{\text {мет }}$ - cross-section area of metal rebars, or

where

$$
\pi D_{\text {2асп }}=\pi D_{2 \text { мет }} / K
$$

$D_{\text {мет }}$ and $D_{\text {асп }}$ - diameters of metal and fiberglass reinforcement respectively, therefore

$$
D_{\text {асп }}=\sqrt{D_{2 \text { мет }}} / K
$$

with $K=2,56$, we obtain

$$
D_{\text {асп }}=0,625 D_{\text {мет }}
$$

For example, $0,625 * 12\left(D_{\text {мет }}\right)=7,5=>D_{\text {асп }}=8$

Based on these grounds for replacement of steel rebars with fiberglass reinforcement the following can be concluded [15]:

- Reinforcement of floor slab between storeys with span width not exceeding 3 meters in case of steel rebars can be assumed as $\varnothing 8$ A-500C with pitch 200

- For reinforcement of floor slab between storeys with the same span width when using fiberglass reinforcement, several options can be assumed: $\varnothing 14$ АКП-СП with pitch $200 \varnothing 10$ АКП-СП with pitch 100

It's worth mentioning that composite reinforcement have the advantage of lighter weight as compared to steel rebars, which is an important factor for the floor slab being reinforced. The reinforcement is produced in the form of rods with length of 6 meters or 12 meters. With diameter up to $12 \mathrm{~mm}$ (included) can be produced in the form of coils (reels), with length 100 meters. With diameter $10 \mathrm{~mm}$ can be produced in the form of coils (reels), with length 50-100 meters. 1 meter of fiberglass reinforcement АCП Ø $10 \mathrm{~mm}$ weighs $0.75 \mathrm{~N}$. Correspondingly, total weight of 2,000 meters of composite reinforcement will be $0.75 \mathrm{~N} *$ $2000=1,500 \mathrm{~N}$. Therefore, 2,000 m of reinforcement ACП $\varnothing 10 \mathrm{~mm}$ will be equal to 20 coils per 100 meters each. One 100-meter coil weighs 75 N. All 20 coils will weigh 1,500 $\mathrm{N}$. All this can be transported in a jeep, car trunk, minibus or light truck. Regarding metallic reinforcement: 1 meter of metallic reinforcement A-500C, Ø $12 \mathrm{~mm}$ weighs $8.9 \mathrm{~N}$. Correspondingly, total weight of 2000 meters of steel reinforcement will be $8.9 \mathrm{~N} * 2,000=$ 
17,800 N. Transportation of this amount of material requires long truck or small hopper barge with a cargo body of proper length.

It can be concluded that steel rebars are heavier than composite reinforcement by 11.87 times. For transportation of this reinforcement large size vehicles must be involved, which is not economically feasible. At the same time, composite reinforcement can be transported in private cars without engaging a carrier company.

While analyzing possible risks of using both types of reinforcement for erection of floor structures for vertical extension of buildings, the economic factor shall also be considered. Real economic effect form using fiberglass reinforcement will be much greater than just the difference in the cost of one running meter [16-18]. Let's consider cost comparison diagram (Fig. 1.).

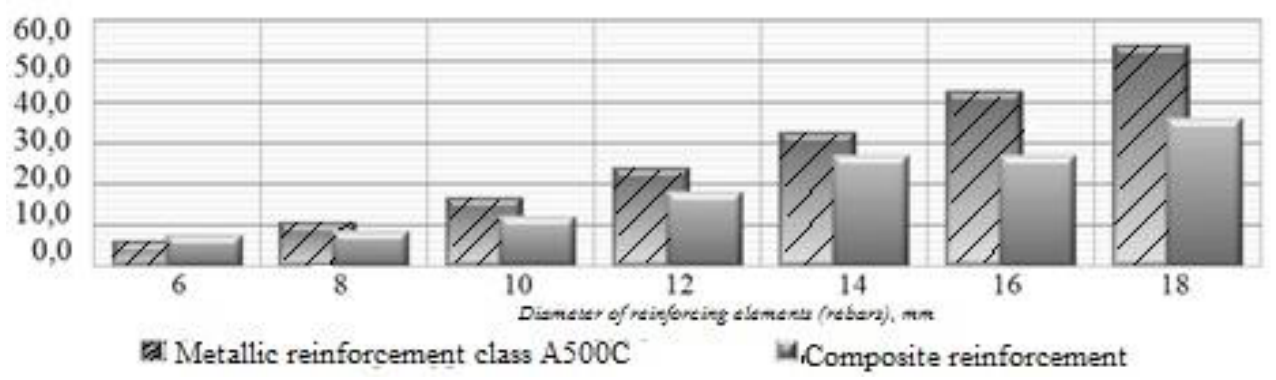

Fig. 1. Comparison of cost per one meter of metallic rebars A500C and fiberglass reinforcement

\section{Conclusions}

As it appears from the data above which are based on the assessment of technical and economic feasibility of using composite reinforcement for strengthening of floor slabs, the following conclusions can be made:

1. Based on comprehensive analysis of bearing capacity of bowing reinforced concrete elements which involves integrated practice of manufacturing, reinforcing and testing of structures, new data was obtained using the method of direct comparison.

2. Today, increasing efficiency of repair and reconstruction works is impossible without improving design solutions to strengthen structures which could provide their reliability, durability and economic feasibility. These indicators are equally dependent on the reduction of costs and labor intensity of production processes of strengthening, efficient utilization of materials and energy, as well as use of new materials.

3. Reinforcement of building structures using composite materials (composite reinforcement) for vertical extension of buildings which due to such properties as high tensile strength, light weight, adaptability to manufacture and resistance to corrosive environment become more and more popular in practice.

4. In the future we will develop and expand practical recommendations for designing reinforcing elements for building structures from composite materials intended for vertical extension. These recommendations will include: effect of concrete elements reinforced with composite materials on bearing capacity; behavior of structure under loading with total percentage of steel and composite reinforcement higher than limiting level; role and efficiency of anchor devices application for overreinforced sections when changing the type of composite material.

5. Introduction of newly developed recommendations will allow increasing reliability and efficiency of strengthening bowing concrete elements using unconventional reinforcing method. 


\section{References}

1. S. Korotaev, V. Kalashnikov, V. Rimshin, I. Erofeeva, V. Kurbatov The impact of mineral aggregates on the thermal conductivity of cement composites. EEC 22, 3, 1159-1164 (2016)

2. V.T. Erofeev, E.V. Zavalishin, V.I. Rimshin, V.L. Kurbatov, M.B. Stepanovich Frame composites based on soluble glass. RJPBC Sciences 7, 3, 2506-2517 (2016)

3. A.L.Krishan, E.A.Troshkina, V.I.Rimshin, V.A.Rahmanov, V.L. Kurbatov Loadbearing capacity of short concrete-filled steel tube columns of circular cross section . RJPBC Sciences 7, 3, 2518-2529 (2016)

4. V.Erofeev, S.Karpushin, A. Rodin, I.Tretiakov, V.Kalashnikov, M.Moroz, O.Smirnova, V.Rimshin, A. Matvievskiy Physical and mechanical properties of the cement stone based on biocidal portland cement with active mineral additiv. SSP 871, 28-32 (2016)

5. Y.M.Bazhenov, V.T.Erofeev, V.I.Rimshin, S.V. Markov, V.L. Kurbatov Changes in the topology of a concrete porous space in interactions with the external medium. ESM 4,4, 219-225 (2016)

6. V.D. Antoshkin, V.T.Erofeev, V.I.Travush, V.I.Rimshin, V.L.Kurbatov The problem optimization triangular geometric line field. MA Science 9,3, 46-50 (2015)

7. V.T. Erofeev, A.D.Bogatov, S.N.Bogatova, V.F.Smirnov, V.I. Rimshin, V.L. Kurbarov Bioresistant building composites on the basis of glass wastes. BBRA 12, 1, 661-669 (2015)

8. A.Krishan, V.Rimshin, S.Markov, V.Erofeev, V.Kurbatov The energy integrity resistance to the destruction of the long-term strength concrete PE 117, 211-217 (2015)

9. V.I.Rimshins, E.A.Larionov, V.T.Erofeyev, V.L. Kurbatov Vibrocreep of concrete with a nonuniform stress state. LSJ 11,11,278-280 (2014)

10. В.И.Римшин, С.И.Меркулов Элементы теории развития бетонных конструкиий с неметаллической копозитной арматурой ПГС 5, 338-342 (2015)

11. D.Duriatti, A.Beakou, R. Levillain Optimisation of the crimping process of a metal end-fitting onto a composite rod CS 73, 3, 278-289 (2006)

12. S.Wen, W.Cai, H.Deng, R.Ke, S.Du, P.Xiong Fault simulation experiment on composite insulators with fiber bragg grating implanted. GJ 39, 1, 81-87 (2013)

13. M.Kumosa, Y.Han, I.Kumosa Analyses of composite insulators with crimped endfittings: part $i$ - non linear finite element computations. CST 62, 9, 1191-1207 (2002)

14. M.Kumosa, D.Armentrout, I.Kumosa, Y.Han, S.Carpenter Analyses of composite insulators with crimped end-fittings: part ii - suitable crimping conditions. CST 62, 9, 1209-1221 (2002)

15. C.Pinto, E.Andrad, L.Silva Study of ionizing radiation on the properties of polyamide 6 with fiberglass reinforcement. RPC 76, 11-12, 1708-1710 (2007)

16. A.Biddah Structural reinforcement of bridge decks using pultruded gfrp grating. CS 74, 1, 80-88 (2006)

17. F.Vilaseca, J.A.Mendez, J.P.Lopez, M.E.Vallejos, I.Barbera, M.A.Pelach, X.Turo, P.M utje Recovered and recycled kraft fibers as reinforcement of pp composites. CEJ 138, 1-3, 586-595 (2008)

18. V.F. Stepanova, A.V. Buchkin, D.A. Ilyin Investigation of the features of the operation of concrete structures with combined reinforcement. AAC 1, 124-128 (2017) 